Europe's Journal of Psychology 3/2009, pp. 82-95

www.ejop. org

\title{
Race Psychology between "Guilty Science" and "Innocent Politics"
}

\author{
Vlad Glăveanu \\ London School of Economics
}

\begin{abstract}
This article will discuss the intricate ways in which, throughout the history of Race Psychology, the "science of race" depended on and reinforced the "politics of race". A brief presentation of the main moments in the history of Race Psychology will be followed by a closer look into the mechanisms through which politics underpins the discoveries of a "guilty" science and science, in its turn, has been used to justify the "innocent" politics of racism and discrimination. Finally, a critical outlook on the past and present of Race Psychology is proposed, one that would simultaneously consider the many facets of this discipline: scientific, political, institutional and ideological.
\end{abstract}

Keywords: Race psychology, science of race, politics of race, anti-racism

Usually the question is "who are the racists in psychology?" But this needs to be reversed: Who is not racist in psychology? Psychology breathes the air of racism.

Howitt and Owusu-Bempah, 1994

Although racism seems to have existed as a way of life for millennia (Rushton, 1995), historians argue that the notion of race originated in the seventeen century, the era in which Europeans met the "outside" world (Lieberman, 1975). In the centuries that followed, philosophers and biologists, using different theoretical frameworks, most of the times joined efforts in supporting racist practices. In psychology, after its emergence as a separate discipline, racism proved to be perhaps "the most versatile and persistent theory" (Howitt and Owusu-Bempah, 1994, p. 9).

This article will offer a very broad overview of the interplay between the science and politics of race and racism, with direct reference to psychological research. Due to its conciseness, this account is aimed at framing a much greater discussion rather than offering a detailed image of this historical development. Considering the above, as well 
as the fact that history itself takes a narrative from, it is expected that some of the arguments presented here in brief will not to be unanimously accepted by everyone, many issues still being subject of on-going debate. For this reason it is essential to emphasize the fact that the present material is first and foremost meant to point to the interchange between science and politics in relation to racial psychology and therefore invite all interested readers to explore further this immensely important issue.

When conceptualizing race and racial differences, science assumes a position of neutrality and objectivity. Positivism works to obscure any ideological construction of race or political agenda (Ahmed, 2008). However, research is in itself a social act and there is no such thing as a "view from nowhere" (Jovchelovitch, 2007) in the production of knowledge.

"The truth surely is that any analysis of the nature of a society's ills is implicitly ideological. It is not being ideological which is the scientific sin here, but the masquerade of not being ideological" (Richards, 1997, p. 277).

This state of affaires is especially problematic for the psychological research of race. Although racism is definitely not a thing of the past, psychology continues to treat this sensitive issue "as something apart from itself, something the discipline studies, and not what it does" (Howitt and Owusu-Bempah, 1994, p. 8). Since race is not a biological but a sociocultural category (Rose et al., 1984; Spears, 1999) the importance it has been given in "scientific" psychology can only be justified by political and ideological reasons. Looking especially at blackness in Western societies, the first section will highlight some significant moments in the history of Race Psychology.

\section{The Long Past and Short History of Race Psychology}

It may be argued that although Race Psychology as a discipline had been a product of the first half of the twentieth century, its origins can be traced far before. In fact, "remarkable continuities" of race and racism in psychology and connected disciplines reverberate up to the present day (Howitt and Owusu-Bempah, 1994).

For centuries Europe has been dominated by the traditional Christian cosmology assuming the unity of 'mankind' as descending from Noah's sons (Rushton, 1995). This also helped to explain physical differences between Europeans, Asians and Africans. But the Biblical story is in fact a myth of degeneration in which Ham's black skinned sons had been cursed for their father's sin (Richards, 1997). 
Early science disregarded this justification and proposed its own terminology, starting, in 1735, with the concept of race and C. Linnaeus's distinction between four human varieties: white, black, red and yellow (Tucker, 1994).

The "old" religious ideas soon clashed with "scientific" ones in what came to be known as the monogenism versus polygenism debate (Lieberman, 1975; Rushton, 1995; Gould, 1996). While the first argued for the scriptural unity of mankind, the second, taking shape in the slave-owning America, envisioned a world of different human species. Although seemingly different, both hypotheses started from the basic assumption that white people are superior to all others.

It was during the second half of the nineteen century that "scientific racism" found its two main pillars in the evolutionary theory and quantification (the birth of statistics; Gould, 1996; Rushton, 1995). The new approach brought biology to the centre and relied heavily on biological determinism, a reductionist explanation (Rose et al., 1984) of human limits (Gould, 1996). The discipline that embodied these assumptions was named "eugenics" (Greek for "well born") by F. Galton (see Larson, 1995) who consequently made the first attempts at quantifying racial psychological differences (Richards, 1997). Many others perfected his work. Among them, H. Spencer is famous for his "pragmatic eugenics" which promoted selective breading and the elimination of "unfit" races (Tucker, 1994).

This "long past" culminated with the emergence of Race Psychology in the 1890s marked by two articles published in "Psychological Review". Measuring reaction time and memory on black samples these materials concluded that better performances in "lower" functions compensate for lacks in higher ones, a hypothesis also tested by the renowned Cambridge Torres Strait Expedition in 1898 (Richards, 1997). Another landmark in this history is T.R. Garth, the only author who named a book "Race Psychology" (1931).

Nevertheless, the vast majority of empirical studies in Race Psychology have been undertaken between 1910 and 1940 by U.S. psychologists, motivated to solve both "Negro education" and immigration issues (Richards, 1997). In both cases the ultimate message was identical: certain races have no hope for improvement.

Much of the history of Race Psychology revolves around the I.Q. debate (see Kamin, 1974). Three important names shaped the course of this debate in America: H.H. Goddard, L.M. Terman, and R.M. Yerkes. They made I.Q. testing popular in the U.S. and turned around Binet's original project of a non-hereditarian intelligence (Gould, 
1996). The first half of the last century became dominated by the search for a measurable, reified (unique), hereditary and unchangeable intelligence, used to rank people (Rose et al., 1984; Gould, 1996).

Parallel with these "developments", and especially during the 1920s, other authors like W.I. Thomas, John Dewey and Franz Boas disputed the race-difference hypothesis arguing that race is an unscientific category and attacking Race studies on methodological grounds (Richards, 1997). A decade later this line of thought became prominent in America especially due to the rise of Nazism. The World-War II propaganda portrayed Nazi Germany as totalitarian and racist and this meant that all its opponents had to be anti-racist (Lieberman, 1975). In the U.S.A. after the war, this new politics became official with the Civil Rights Act of 1964 and the 1965 Voting Rights Act (Sears et al., 2000).

Would this era be the end of a racist Race Psychology in the West? Unfortunately, the "spirit" of Race Psychology as a "racist science" is very much alive and just differently clothed in modern times (Howitt and Owusu-Bempah, 1994). For example, as recently as 2005, Rushton and Jensen argued that the 15 to 18 points in I.Q. that separate blacks and whites stand their ground as they did when first measured. They consider this difference as largely heritable, and resting in brain size differences.

Why do these claims tend to "recur every few years with a predictable and depressing regularity" (Gould, 1996, p. 27)? To answer this question we have to turn to the intricate relationship between science, politics, ideology and social practice. Critically looking into the past of this "long-running saga" (Richards, 1997) is the aim of the following two sections.

\section{"Guilty Science": Politically Enforced Knowledge}

In most societies science is accepted as the ultimate authority in deciphering and understanding the physical and social reality (Zack, 2002). The scientific project in its positivist dimension talks about the absolute objectivity of scientific data and impartiality of the researcher. Those involved in race studies over the decades have particularly used this image as a shield protecting them from public scrutiny:

"We firmly believe that we have no political, no religious and no social prejudice... We rejoice in numbers and figures for their own sake" (Pearson and Moul, 1925, cited in Tucker, 1994, p. 6). 
Dissipating the "smoke-screen" hiding the racism (Howitt and Owusu-Bempah, 1994) of the pre-history and history of Race Psychology, it becomes clear that one of its main "engines" is political. Science is socially embedded in the sense that it has both social determinants and functions (Rose et al., 1984). In the almost special case of psychology, ideology not only guides the interpretation of available data but it also determines the very data a scientist looks for (Richards, 1997).

Initially the political agenda enforcing scientific efforts has been set by colonialism and slavery. This is how, from early beginnings, the myth of African dependency was born and with it the image of blacks as children that need to be protected (Howitt and Owusu-Bempah, 1994). Science found the child metaphor to be perfect for its social purposes with just one amendment: unlike children, "primitives" are in a state of "arrested development". The patronisingly paternalistic goals (Richards, 1997) of this vision made scientists the best allies of Western political leaders throughout the nineteen century.

This strange alliance continued and, with the institutional changes and new antiracist laws brought up in the twentieth century, it only became more subtle and, by this, more dangerous. The main purpose of the "scientific" Psychology of Race became that of justifying social disadvantage. By continually stressing the genetic argument researchers have in fact argued that:

"the social disadvantage of black people stems from their biological disadvantage and not vice versa" (Howitt and Owusu-Bempah, 1994, p. 7).

A main area in which many psychologists were interested in making this point has been education. Bringing to the front what was supposed to be an inherited I.Q. difference, some argued that no extra-schooling can cover this gap (see Eysenck, 1971). It is not hard to observe the social and political stake of such strong claims and the vicious circle they produce: by considering differences as predetermined, funds are cut and in turn this can only lead to further disadvantage for those in need.

Although the examples of politically enforced science are numerous, one question soon arises: are we dealing with genuine dishonesty, intellectual naivety or unthinking conformity? (Richards, 1997). Gould's (1996) work is enlightening in this case. By reanalyzing data sets of seminal studies in the (pre)history of Race Psychology, he distinguished between those that un-deliberately read data in a prejudiced way (like Morton and Broca and their craniometry) and those who 
consciously fabricated data to fit their position (like the twin studies of Cyril Burt and Goddard's alteration of photographic evidence).

Why and how does politics influence science? One way of answering this question is that all knowledge is produced in institutions (Young, 1990) and these institutions depend on funding (Richards, 1997). Maybe the emblematic case in this regard is that of the Pioneer Fund and the Mankind Quarterly journal (Lane, 1995; Sedgwick, 1995). Founded by a man who advocated the repatriation of Blacks to Africa, the Pioneer generously gives away more than a half million dollars a year (for a review see Tucker, 2002).

In concluding:

"Psychology is instrumental in maintaining the societal status quo by (a) endorsing and reflecting dominant social values, (b) disseminating those values in the persuasive form of so-called value-free scientific statements, and (c) (...) portraying the individual as essentially independent from sociohistorical circumstances" (Prilleltensky, 1989, p. 800).

The "scientific hell" (Tetlock, 1994) opened loose with the collapse of credibility in psychology as a science has been largely determined by the fact that whenever men in power need scientific arguments, there are usually enough psychologists willing to supply them (Gould, 1975).

\section{"Innocent Politics": Scientifically Enforced Policies}

The relationship between race and politics has been addressed by a growing literature covering various geographical regions: Britain (Layton-Henry and Rich, 1986; Shamit, 1992), United States (Perry, 1996; Sears et al., 2000), Bahamas (Hughes, 1981), South Africa (Robertson and Whitten, 1978) etc. Most of these show how the stories told in numbers (Cole, 1995) are used to make oppression seem rational and, to a certain extent, unavoidable (Tucker, 1994). This type of "innocent" politics relies heavily on bio-psychological research in the sense that:

"academic discussions of race have frequently been incorporated into sweeping and draconian social policies which serve white people's interests" (Howitt and Owusu-Bempah, 1994, p. 3). 
As argued in the previous section, "true knowledge" has never been passive and objective but actively involved in social issues. Black people from Africa or the Caribbean, Indians, Eastern European immigrants and many other categories had to be "dealt with" by the dominating groups. "Scientific racism" offered the answers oppressors were looking for: inequalities stem from inherited differences (Rose et al., 1984), there is a hierarchy of races (Gould, 1996) and social action must be taken to protect genetic "heritage". The following paragraphs will present supporting examples for this mechanism.

The fact that eugenics influenced Hitler's politics was believed by many (see for example Weikart, 2004). Nazi ideology has found the justifications it needed for acts of euthanasia and genocide in the biological improvement of the human specie. The evolutionary view of survival of the fittest made immoral means (like artificial selection) pale in comparison to the supreme goal. Competition and conflict became the natural state, things to be valued by right-wing racists. Under these conditions, actions towards a programme of "race hygiene" (Howitt and OwusuBempah, 1994; Weingart, 1989) soon followed and Hitler's personal political agenda against certain populations (Jews, Gypsies etc.) completed the scheme and oriented practical action.

In the years preceding World War II similar "scientific" ideas were helping politicians to deal with "inferior races" on the other side of the Atlantic as well. After Yerkes persuaded the U.S. army in World War I to test 1.75 million men and discovered an unsatisfactory mental age of 13 (Gould, 1996), strict immigration politics became a major concern. Psychologists offered their conclusion: there is a decline in intelligence due to the fact that "low-quality" immigrants from each race reach America. Everyone's attention turned towards immigration law and the government took "scientific" evidence seriously reducing yearly quotas for different nations through the 1924 Restriction Act. Nordic blood was supposed to be of the highest quality, followed from a distance by Alpine and Mediterranean (Kamin, 1974). As a consequence, hundreds of thousands were killed by Nazi persecution, being denied admission to the Unites States.

The main problem with the interpretation of I.Q. testing was that of assuming that it represented the real level of intelligence and that this level is inherited and basically fixed. Even more, I.Q. was considered to predict the future of the person (Gould, 1996) as well as his/her capacity to learn (Eysenck, 1971). For this reason, in the eugenics era, universal education was considered simply a waste of resources (Tucker, 1994). Racist politics never stopped relying on racist science. In the 1920s for 
example, authors like C. Cannon found that 89 percent of Blacks tested were "morons" and argued that:

"a public school system, preparing for life young people of a race, 50 percent of whom never reach a mental age of 10, is a system yet to be perfected" (cited in Gould, 1996, p. 261).

Similar arguments are found also in Jensen's articles, with further indications for blacks to be educated "for the more mechanical tasks to which their genes predisposed them" (in Rose et al., 1984, p. 19). Unfortunately, in what education is concerned, the ethos of Race Psychology has not run out to the present day.

\section{Reforming the Psychology of Race / Racism}

It is said that those who forget history are condemned to repeat it. It has certainly been the case of psychology where, although the obsession with racial differences contributed nothing to the understanding of cognition (Tucker, 1994), it continues to haunt the discipline. As Howitt and Owusu-Bempah (1994) explain, this happens because psychology hardly takes racism seriously. Continuing their argument, the two authors show that this problem is so pervasive because "psychology's racism reflects the complex racist society of which it is part" (idem, p. 1). Any serious effort to at least diminish racism must first consider changes in social structure and power relations (Lieberman, 1975; Spears, 1999).

In the past years there has been an increased awareness of this difficulty among psychologists as well as an active search for solutions such as: more rigorous evaluation of counterfactual claims (Tetlock, 1994), researchers' recognition of their preferences (Gould, 1996), individual and collective reflexivity and responsibility in the act of teaching and research (Ahmed, 2008). The focus on reflexivity is central to a Critical (Social) Psychology of Racism / Anti-racism (Howarth and Hook, 2005), an approach interested to reveal exactly how Race is socially constructed in scientific research and social practices in ways that perpetuate oppressive power relations (Ahmed, 2008).

In line with this more recent perspective and the arguments put forward in this article concerning the link between science and politics, I conclude that the history of Race Psychology has traditionally been presented as disconnected from its institutional, political and ideological functions (see Figure 1). 


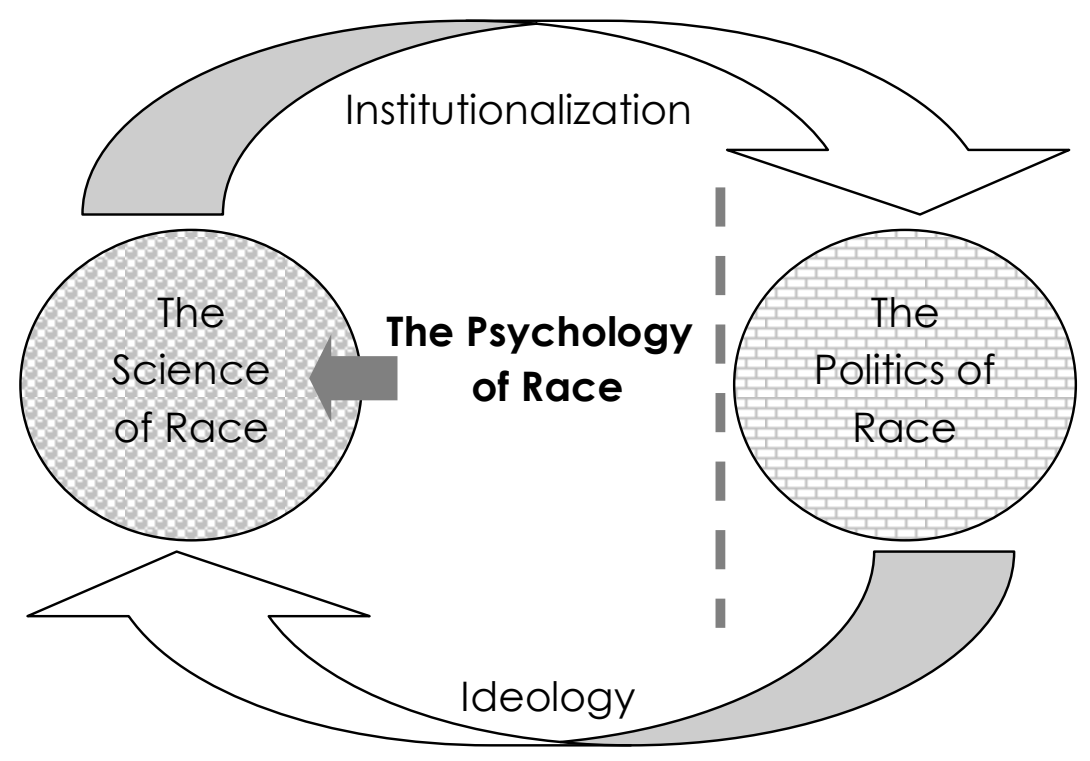

FIGURE 1. A non-critical understanding of Race Psychology

In order to demythologize science as a "truth-making machine" (Gould, 1975), we have to recognize the circular relation between science and politics in the history of Race / Racism / Anti-racism Psychology and also the specific nature of these connections. More precisely, how scientific knowledge becomes institutionalized and socio-political charged ideologies guide scientific thought (Willingham, 1986). As suggested in Figure 2, this approach would correspond to a Critical outlook on Race Psychology, past and present. The process of addressing simultaneously Race and "racism" as science, politics, institutionalization and ideology is an ongoing one, never fully completed, always in the making (Hook and Howarth, 2005). 


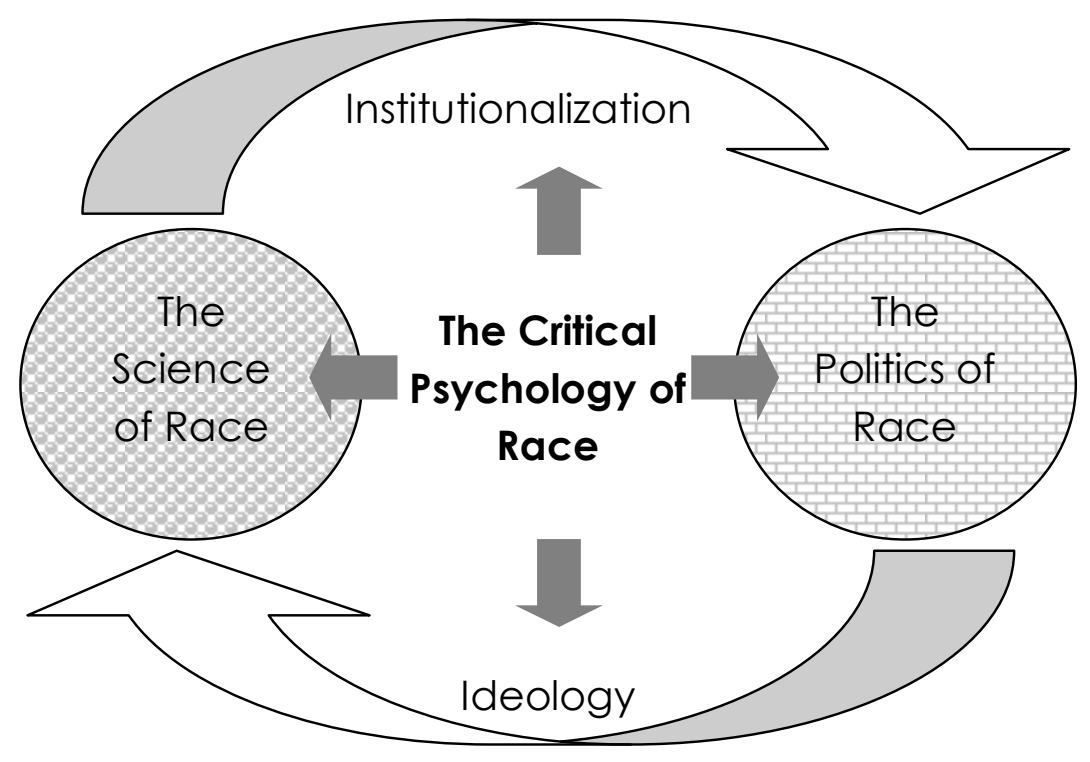

FIGURE 2. A critical understanding of Race Psychology

As Rose et al. (1984) recommended, scientists should ask themselves two questions: if their theories are true and how are they socially and politically embedded. Darwin intuitively perceived this interplay between science and society and, foreseeing the future, said that "if the misery of our poor be caused not by the laws of nature, but by our institutions, great is our sin" (cited in Gould, 1996, p. 27). From a critical perspective the first question that needs to be asked would be: What if this misery is caused by our science?

\section{References}

Ahmed, B. (2008). Teaching Critical Psychology of 'Race' issues: Problems in Promoting Anti-racist Practice. Journal of Community \& Applied Social Psychology, 18, pp. 54-67.

Cole, K.C. (1995). Innumeracy. In R. Jacoby and N. Glauberman (eds.), The Bell Curve Debate. United States: Times Books, pp. 73-81.

Eysenck, H.J. (1971). Race, Intelligence and Education. London: Temple Smith.

Garth, T.R. (1931). Race Psychology: A Study of Racial Mental Differences. London: McGraw-Hill Publishing. 
Gould, S.J. (1975). Racist Arguments and IQ. In A. Montagu (ed.), Race and IQ. New York: Oxford University Press, pp. 145-150.

Gould, S.J. (1996). The Mismeasure of Man. London: Penguin.

Hook, D. \& Howarth, C. (2005). Future Directions for a Critical Social Psychology of Racism/Antiracism. Journal of Community and Applied Social Psychology, 15, pp. 506-512.

Howarth, C. \& Hook, D. (2005). Towards a Critical Social Psychology of Racism: Points of Disruption. Editorial. Journal of Community and Applied Social Psychology, 15, pp. 425-431.

Howitt, D. \& Owusu-Bempah, J. (1994). The Racism of Psychology: Time for change. New York: Harvester Wheatsheaf.

Hughes, C. (1981). Race and Politics in the Bahamas. New York: St. Martin's Press.

Jovchelovitch, S. (2007). Knowledge in Context: Representations, Community and Culture. London: Routledge.

Kamin, L.J. (1974). The Science and Politics of I.Q. Potomac: Lawrence Erlbaum Associates.

Lane, C. (1995). Tainted Sources. In R. Jacoby and N. Glauberman (eds.), The Bell Curve Debate. United States: Times Books, pp. 125-139.

Larson, E.J. (1995). Sex, Race, and Science: Eugenics in the Deep South. Baltimore: The Johns Hopkins University Press.

Layton-Henry, Z. \& Rich, P. (eds.) (1986). Race, Government and Politics in Britain. Basingstoke: Macmillan.

Lieberman, L. (1975). The Debate over Race: A Study in the Sociology of Knowledge. In A. Montagu (ed.), Race and IQ, New York: Oxford University Press, pp. 19-41.

Perry, H.L. (ed.) (1996). Race, Politics, and Governance in the United States. Gainesville: University Press of Florida.

Prilleltensky, I. (1989). Psychology and the status quo. American Psychologist, 44(5), pp. 795-802. 
Richards, G. (1997). 'Race', Racism and Psychology: Towards a Reflexive History. London: Routledge.

Robertson, I. \& Whitten, P. (eds.) (1978). Race and Politics in South Africa. New Brunswick, N.J : Transaction Books.

Rose, S., Kamin, L.J. \& Lewontin, R.C. (1984). Not in Our Genes: Biology, Ideology and Human Nature. Harmondsworth: Penguin.

Rushton, J.P. (1995). Race, Evolution and Behavior. New Brunswick: Transaction Publishers.

Rushton, J.P. \& Jensen, A.R. (2005). Wanted: More Race Realism, Less Moralistic Fallacy. Psychology, Public Policy, and Law, 2, pp. 328-336.

Sedgwick, J. (1995). Inside the Pioneer Fund. In R. Jacoby and N. Glauberman (eds.), The Bell Curve Debate. United States: Times Books, pp. 144-161.

Sears, D., Hetts, J., Sidanius, J. \& Bobo, L. (2000). Race in American Politics: Framing the Debate. In D. Sears, J. Sidanius and L. Bobo (eds.), Racialized Politics: The Debate about Racism in America. Chicago: The University of Chicago Press, pp. 1-43.

Shamit, S. (1992). Race and Politics in Britain. Hemel Hempstead: Harvester-Wheatsheaf.

Spears, A.K. (1999). Race and Ideology: An Introduction. In A.K. Spears (ed.), Race and Ideology: Language, Symbolism, and Popular Culture. Detroit: Wayne State University Press, pp. 11-58.

Tetlock, P. (1994). Political Psychology or Politicized Psychology: Is the Road to Scientific Hell Paved with Good Moral Intentions? Political Psychology, 15(3), pp. 509-529.

Tucker, W.H. (1994). The Science and Politics of Racial Research. Urbana: University of Illinois Press.

Tucker, W.H. (2002). The Funding of Scientific Racism: Wickliffe Draper and the Pioneer Fund. Urbana: University of Illinois Press.

Weikart, R. (2004). From Darwin to Hitler: Evolutionary Ethnics, Eugenics, and Racism in Germany. New York: Palgrave Macmillan. 
Weingart, P. (1989). German Eugenics between Science and Politics. Osiris, II, vol. 5, pp. 260-282.

Willingham, A. (1986). Ideology and Politics: Their Status in Afro-American Social Theory. In A. Reed (ed.), Race, Politics and Culture: Critical Essays on the Radicalism of the 1960s. New York: Greenwood Press, pp. 13-27.

Young, R. (1990). White Mythologies: Writing History and the West. London: Routledge.

Zack, N. (2002). Philosophy of Science and Race. New York: Routledge.

About the author:

Vlad Glăveanu has a BA in Psychology from the University of Bucharest, an MSc in Social and Cultural Psychology from the London School of Economics and is currently pursuing his doctoral studies at the LSE. He is Editor of Europe's Journal of Psychology and had published mainly in the fields of social, organisational and educational psychology. His current research explores creativity from a sociocultural perspective ("Paradigms in the study of creativity: Introducing the perspective of cultural psychology", New Ideas in Psychology, 2009).

Contact: v.p.glaveanu@lse.ac.uk 